\title{
Forestry at the millennium - Pitfalls and opportunities
}

\author{
by Jack Ward Thomas ${ }^{1}$
}

For forty-two years I have had the good fortune to work as a professional conservationist in North America and various other places in the world. Thirty of these years were spent with the U.S. Forest Service -27 years as a researcher and three years as Chief Forester.

Before becoming Chief, I spent much of the preceding three years heading various teams of scientists dealing with what is now commonly referred to as "the spotted owl crisis." As Chief, I dealt with bringing the U.S. Forest Service to grips with a new mission that involved preservation of biodiversity, dealing with questions of sustainability, and instituting a new approach to forest management, referred to as "ecosystem management." Change - and the resulting resistance to that change - made life interesting, educational, and wearing.

The move to ecosystem management approaches does not, to my mind, represent a revolutionary change. Rather, I view that shift as an evolutionary step on a long and continuing journey.

For decades professional conservationists have known that natural resources, and their use and management, needed to be considered in an enlarged context of space, time, and interactions of ecology, economics, law, and social expectations. With the advent of remote sensing, Geographic Information Systems technology, computer capabilities to handle huge amounts of data, and the necessity to meet legal mandates under operative laws (particularly the Endangered Species Act), have made it imperative to broaden assessments and management planning.

This attention to retention of biodiversity and sustainability of forests has ever more rapidly evolved. The only mention of "ecosystems" that exists in the laws of the United States is the stated purpose of the Endangered Species Act of 1979 to "... preserve ecosystems upon which threatened or endangered species depend." Given the constantly increasing numbers of threatened and endangered species, this is a compelling reason for an ecosystem management approach, as opposed to dealing with one species at a time. Experience in dealing with the old-growth issue in the Pacific Northwest, when combined with the legal requirements of protecting threatened terrestrial species and runs of anadromous fish was further evidence of the demand to move to a broader approach in assessment and management.

${ }^{1}$ Chief Emeritus, USDA Forest Service. Boone \& Crockett Professor of Wildlife Conservation, School of Forestry, University of Montana, Missoula.
Ecosystem management entails four alterations to present approaches to planning and management. First is the need to assess conditions in a much-expanded scale. Second is the demand to consider longer time frames. Third is the requirement to consider ecological, economic, legal, and social ramifications of natural resource planning and management, both singly and in interaction. Fourth is the requirement to fully consider humans and their needs and demands.

Critics of the approach correctly point out that these criteria are nebulous and "you can define an ecosystem however you want." They are precisely correct as far as the logic is applied. What they miss, or do not want to see, is that this is merely a concept until it is placed into context.

Context requires the definition and rationale for that definition of the four factors and, perhaps, others. At the moment, context is provided once the situation is defined. Though I think the use of the term "ecosystem management" is appropriate, those who want to argue can call it by any name they like. How about "Largescale/Long-term/Multi-variate/ Human-oriented Planning and Assessments," or perhaps some other set of words. To paraphrase Shakespeare, "A rose by any other name would smell as sweet" - or as rotten.

The critics simply do not like assessment of conditions across ownership boundaries. They sense some nefarious plot - just what sort of plot they don't know.

After going over all of this in a Senate Committee hearing, a Senator told me he did not like "ecosystem management," and just might put language in the Budget Bill to make ecosystem management against the law. With all due respect, I suggested that the Senator might practice this legal marvel by going out to the beach and commanding that the tide retreat. I believe that ecosystem management, by whatever name, is simply a concept whose time has come.

It is my observation that there is a common path that foresters all over the world are following in their professional evolution - no matter what the specific circumstances. Foresters around the world, I suggest, are distributed at different way stations along that path. Factors that influence that location include, at least, the following factors: 
1. How long has scientifically based forestry been practised?

2. How were the foresters trained?

3 . What is the educational level of the population?

4. How wealthy is the country?

5. What is the form of government, e.g., is the country a democracy?

6 . Are the forests publicly or privately owned?

7. How much influence on government do large corporations exert?

8. Is there a well-developed and influential environmental community?

Think on these questions as I move along with what I have to say. Let me begin with a few provocative statements to pique your interest - though I certainly believe these statements to be true.

First, no professional group active in the natural resource arena has so declined in professional prestige in the eyes of the public over the last 25 years as have foresters. Second, by and large, foresters are no longer considered pre-eminent leaders in the conservation movement that they founded and nurtured in its infancy. Third, foresters, by and large, have been excruciatingly slow to take into account increasing public concerns with forest management and distress with visual impacts, watershed effects, threats to biodiversity, concerns with sustainability, and autocratic single-focus decision-making. Foresters are now paying a price in terms of increasing public challenges to their wisdom and prerogatives.

Aldo Leopold, whom I, and many other conservationists, consider the foremost philosopher concerned with matters of human relationships to the good earth, was trained as a forester at Yale. He worked for several decades and in several capacities for the U.S. Forest Service.

He was proud of being a forester and identified himself as such throughout his professional life. Yet, Leopold is now recognized as "the father of wildlife management" and as the author of A Sand County Almanac, which is widely acclaimed for its expansion of ethics from the human realm to the earth itself.

Leopold hypothesized over fifty years ago that foresters tended to be one of two types. He called this division the "A/B Cleavage."

The A Group, he opined, approached forestry much as a farmer approaches the growing and harvesting of cabbages. Trees are considered a crop to be produced, harvested, and marketed with maximum efficiency and minimal distractions for other purposes.

The B Group, he hypothesized, was more attuned to considering forests a biological entity that involved much more than the trees that define the forest. Such foresters, he said, exhibited the stirrings of what he called an "ecological conscience." He made the common-sense observation that "the first rule of intelligent tinkering is to save every cog and wheel."

$\mathrm{He}$ maintained that foresters, and others that manipulated the good earth, should expand ethical consideration beyond the human realm to the natural world. Leopold even suggested a means of measuring that ethical relationship. This has been known as Leopold's Land Ethic: "A thing is right when it tends to preserve the integrity, stability, and beauty of the biotic community. It is wrong when it tends otherwise."

Leopold was a dreamer and a philosopher, but he was no fool. He knew that we humans, as all other creatures, must exploit our environment in order to live. The question, then, is not whether - but how - that exploitation is to occur.
In North America, Group A foresters, whose focus was fixed on the harvesting and growing of trees on an "agricultural model," were the dominant group in forestry until the last quarter of the century. That attitude remains dominant on industrial forest lands - particularly in the southeastern United States. In the agricultural model of forestry, determined efforts are made to meet the following objectives:

1) Trees, both species and individual trees, that will grow fastest and straightest, including genetically "improved" planting stock, are selected to dominate a site.

2) Competition - plant and animal - for the selected trees is controlled or, if possible, eliminated. This likely requires the use of pesticides and herbicides. Additional stand tending includes thinning to remove trees deemed inferior in form or growth rate, and to concentrate growth factors, i.e., moisture and nutrients on selected stems. This may include fertilization and/or irrigation.

The investment in the trees, which can be very high considering the time cost of money, is vigorously protected against any threat - including insects, disease, and fire. Efforts at protection, besides herbicides and pesticides, may involve fire lanes, access roads, and fire fighting.

The tree crop is harvested at what is judged to be the most fortuitous economic time. The stand is "regenerated" as soon as possible with a selected species and genotype. Then, if all goes well, the cycle is repeated.

When questioned as to the long-term efficacy of such an approach, or the inherent broad-scale ecological effect, foresters too frequently fall back on insistence on professional prerogatives. In other words, "Trust me, for I am a forester."

Over the past two decades there has been a growing backlash against the Group A approach to forestry carried too far and applied too broadly or in inappropriate circumstances. This backlash has been most pronounced in democracies, particularly in nations with large forested areas in public ownership where Group A forestry has been in vogue for many decades. The backlash is exacerbated when the population is relatively well educated and wealthy. Also playing a role is the presence and increasing influence of a community deeply concerned with environmental values.

The primary reason for the loss of faith in foresters by a significant and vocal segment of the population in such countries has been the Group A foresters' high level of dependence on management of even-aged stands. The even-aged management approach depends on clear-cutting (or some facsimile thereof, e.g., seed tree or shelterwood) to prepare for stand regeneration.

The clearcutting stage of even-aged timber management may be efficient in both harvesting and regeneration, but the vast majority of people thinks clearcuts are ugly. Such cuts are ugly enough in any form, but when the cuts are laid out in squares or some other regular geometric shape, they are, by any measure, doubly ugly.

There are few beyond foresters, or perhaps wildlife biologists concerned about early successional species, that can see the beauty of a clearcut. But foresters persisted in such activities, without adequate explanation to the citizenry, long past the onset of a building public outcry.

Group A forestry works best on gentle terrain which moderates visual impacts and lessens environmental effects. Gentle terrain greatly eases the costs and environmental effects of 
stand tending and road construction and maintenance. Group A forestry, in many circumstances, has been highly successful. This was particularly true when converting virgin stands to managed stands or when reconverting agricultural lands to forests.

Trouble began to develop when such approaches were extended to steeper and steeper ground and less and less productive sites. Visual effects and environmental risks increased. Collectively, foresters are just now realizing that in a democracy they will practice forestry at the discretion of the people as a whole. A forester's prerogatives in the end are what the people say they are - no more and no less.

The international backlash against Group A forestry and foresters is developing into a professional lurch toward Group $B$ forestry and foresters. In the short term, this takes on the mantle of all-aged forestry based on single-tree or small selection harvesting. For example, my predecessor as Chief of the U.S. Forest Service, Dale Robertson, announced a policy of significantly reducing clearcutting and embarkation on ecosystem management. That policy remains in force.

A major Canadian corporation has issued a similar pledge. These are significant policy shifts in response to the public backlash against Group A forestry. Were these changes instituted because new research indicated that all-aged forestry was superior? Or was this simply a recognition that the public was increasingly vigorous in objection to Group A forestry? Clearly, these decisions were political in nature. Clearcutting simply became politically incorrect. There is nothing wrong with politics. That is how big decisions are made in a democracy.

These decisions may be politically sensitive and necessary. But the decisions, particularly if universal, will likely prove unwise from economic, ecological, and social perspectives at least in some cases.

I am old enough and long enough in the conservation and forestry business to remember why the move to even-aged timber management ensued. The reasons were very simple. In many cases, perhaps most, single-tree or small group selection harvesting worked poorly. That was because of some combination of the following reasons:

1. Results were unpredictable, i.e., results often occurred that were not expected.

2. Economic realities produced a tendency to "high grade" stands for trees with enough value to make a profitable timber sale.

3. Felling and removal of individual trees produced damage in the residual stand that produced deformities or facilitated disease.

4. Many more roads and skid trails were required with increased costs and increased impact.

5. Harvest entries occurred at shorter intervals.

6. Harvesting costs were relatively high, as it was necessary to cover much greater areas to obtain the same volume of harvest.

7. Harvesting became increasingly difficult and expensive with steeper slopes.

8. There was a lack of research data to guide management in many forest conditions.

So, given what I have said so far, what about forestry in the next millennium? From what I have said many of you might conclude that I believe forestry and the forest industry have a grim future.

I think not. But if what could be a grim future is not to materialize, foresters must come to grips with the reality that forestry is too complex and too important to be left solely to foresters. Increasingly, forestry involves teams of specialists - silviculturalists, entomologists, ecologists, fish and wildlife biologists, soils scientists, hydrologists, landscape architects, economists, engineers, logging specialists, social scientists, conservation biologists, and others.

Again, I remind you, that in a democracy we practice our profession at the sufferance of the people at large. And that will apply, ultimately, to private as well as public lands. This will of the people will come to bear first on the public's lands - the lands owned by all the people. It is no longer enough to stand tall, flash our union cards that proclaim us a "registered professional," and ask the public simply to trust us - and our judgement.

Frankly, the citizenry has looked at us and at some 75 years of our actions, and is less than satisfied with what they see. Leopold noted that we write our signatures on the landscape where they can be seen long after we have returned to the earth. We need to improve our penmanship.

We have been too strongly protective of our professional prerogatives. We have failed to see and come to grips with our hubris even as public confidence wanes.

We have forgotten how to lead, how to educate, how to inform, and how to inspire the critical mass of support required from the citizenry. We have far to go to regain the status that we held - and deservedly - for so long.

I see awakenings in the conservation professions that I identify as encouraging. In the United States, progressive companies have come together in an effort to ensure sustainable forest practices. The effort has been labelled the Sustainable Forestry Initiative. I serve as a member of the "Expert Review Panel," whose job is to ensure that rhetoric is converted to a "kinder, gentler forestry" on the ground.

This is not and will not be an easy journey - and there is far to go. Yet the journey has begun.

Some of my friends of the environmental persuasion have accused me of consorting with the timber industry. I plead guilty. I never question an epiphany that occurs along the journey we all travel to Damascus. The reason, or the messenger of the epiphany, is not nearly so important as the resultant conversion.

The reaction to the citizens' backlash has, thus far, been more pronounced in the United States than in Canada. For example, the annual cut from the National Forests has dropped from $12.5 \mathrm{BBF}$ to $3.5 \mathrm{BBF}$ over the past 15 years. And, even now, one influential environmental organization is pushing for a "zerocut option."

Is there a moral question here? Consider that the population continues to grow with a doubling of the population expected by the mid- $22^{\text {nd }}$ century. That seems to be accepted

The consumption of wood and wood fibre per capita is the highest in the world - and increasing. No one much seems to question that. The gross national product and per capita income are projected to continue to increase. Government policy is aimed at increasing consumption. There are few dissenting voices.

Where do the people of the United States expect to get the wood and wood fibre that population and economic growth portends? The people of the United States, evidently, intend to import the wood required to fuel the ever-rapacious economic engine that delivers the "good life." 
Obviously, in the short term, much of that wood will come from Canada. But the increasing environmental concerns of the heavily urban population, and industry concerns over "green labelling" for imports into Europe and, likely, the United States, coupled with increasing domestic consumption, will limit wood available for export and drive costs and prices of exports up.

The United States will then turn more and more to imports from countries desperate for foreign exchange - particularly hard U.S. dollars. Those countries, by and large, have neither the laws nor the infrastructure to practice sustainable forestry with any definitive attention to questions of preservation of biodiversity. And, to make matters even worse - or more ludicrous - the United States has essentially abandoned all efforts to provide significant technical assistance to those countries. It is well to ponder whether this set of circumstances is not only hypocritical but even immoral.

These questions of morality related to domestic timber supply are easily extended to the internal affairs of North America, particularly the United States. Forests, almost by definition, exist primarily in rural areas, sometimes very remote, where timber harvest and forest management produce a primary source of jobs and income.

Voters, on the other hand, are quite obviously concentrated in urban centres. As a harbinger of the future, I note that Canada is even more urbanized than the United States. Look south. Perhaps you will see the "ghost of forestry future." Remember, in a democracy, the majority rules.

As a result, in a democracy the consequences of the rising tide of concern over what is appropriate in the treatment of forests settles disproportionately on rural areas heavily dependent on natural resource extraction. A look back in time reveals that communities that were built almost solely on a natural resource extraction base (logging, mining, fishing) usually disappear over time - or adapt to changed conditions - due to a declining resource base combined with dramatic increases in efficiency in extraction and processing.

Inescapably, this leads to the conclusion that working things out at the most local level possible is the best defence against rural communities being swept over in the tide of decisions made at national or state (provincial) levels.

Recent history indicates that adamant opposition to change by extractive industries and persons employed in those industries will ultimately backfire. For example, consider the extraction of timber from the national forests in the Pacific Northwest of the United States.

As the government came to grips with the questions of ensuring the welfare of threatened or endangered species (northern spotted owls, marbled murrelets, and anadromous fish), the timber industry could have, at various moments, settled for 2-3\%, $8-10 \%$, or $40 \%$ reduction in annual timber harvest levels - but ended up with a reduction of $75 \%$. This resulted from the continued rapid fragmentation and simultaneous diminution of lands in old-growth forests. Time and continued levels of cutting of old growth eroded options to deal with the crisis of the spotted owl.

What was the lesson to be learned? Environmental concerns of the citizenry will grow - both with increasing environmental awareness and as the signature of foresters is scrawled across the landscape as clear-cut units in virgin forests. Early planning, with full participation from all stakeholders, will, I believe, produce a more palatable result for all concerned. Remember that time coupled with the status quo eats away options and very rapidly.

What has been described as a "kinder, gentler forestry," with some assurance of sustainability and preservation of biodiversity, is, I believe, the future of forestry in the next millennium in North America.

Not only will the rising environmental concerns of an increasingly urban population dictate that result. The probability of a continued rise in "green labelling" efforts in Europe and North America, perhaps coupled with international accords, will tend to reinforce the trend to kinder, gentler forestry. If that proves to be true, foresters, governments, resource industries, and those who depend on forest products are faced with three choices. Those choices are: lead, follow, or get out of the way.

I suggest leadership as far and away the best option. Foresters, after all, were the midwives of the modern conservation movement in North America. Foresters are equally capable of being conservation leaders for the post-modern period of conservation. But if that is to be true, there must be a conscious decision in the community to be leaders, thereby rejecting the options of following the lead of others, getting out of the way, and, quite simply, being run over.

Leadership will require, in my opinion, embracing the evolving concept of ecosystem management. These are, indeed, "the worst of times, the best of times" for forestry and foresters as we approach the twenty-first century.

The period of 1895 - 1905 was a defining decade for conservation in North America that set the course for the $20^{\text {th }}$ century. I firmly believe that the period $1995-2005$ will be the defining decade for conservation in the $21^{\text {st }}$ century. The stage is set. What role do we choose to play?

We have a largely unwritten script in hand. What to do? Do we try for a leading role? Or, perhaps, a supporting role is best? Or we can retreat from the stage to the audience.

The time is ripe. The choice is ours. 